\title{
Private placement, share prices, volume and financial crisis: an emerging market study
}

\begin{abstract}
Firms are increasingly resorting to private placements in recent years, yet there is no published study of emerging markets. There is a unique opportunity to study this behavior during a severe financial crisis, when firms resorted to private placements to recover financially distressed firms. Our analysis using data over fifteen years shows (a) a significant 2-3\% positive share price reaction, affirming asymmetric information effect, (b) a significant volume activity, and (c) the price impact is different across a period of a major financial crisis. If the proceeds from placement are earmarked for investment, share price is negatively (positively) correlated during the crisis (non-crisis) periods. Our finding on regulation is inconsistent with prior reports in developed markets: this is explained by the stricter restrictions on trading of private issues in emerging market. These results provide modest new contributions to the literature on private placements.
\end{abstract}

Keyword: Private placement; Wealth and volume effect; Financial crisis; Ownership concentration; Information asymmetry; Long run performance 